\title{
MOLECULARY CONFIRMED, CYTOGENETIC REMISSION IN A CASE WITH MYELODYSPLASTIC SYNDROME TREATED WITH AZACITIDNE
}

\author{
Irina Panovska-Stavridiss ${ }^{1}$, Martin Ivanovski ${ }^{1}$, Sanja Trajkova ${ }^{1}$, Aleksandra Pivkova-Veljanovska ${ }^{1}$, \\ Marija Popova-Labaceska ${ }^{1}$, Nadica Matevska-Geshovska ${ }^{2}$, Predrag Noveski ${ }^{3}$, \\ Dijana Plaseska-Karanfilska ${ }^{3}$, Lidija Cevreska ${ }^{1}$, Aleksandar J. Dimovski ${ }^{2}$ \\ ${ }^{1}$ University Clinic of Hematology, UKIM - Faculty of Medicine, Skopje, Republic of Macedonia \\ ${ }^{2}$ Center of Biomolecular Pharmaceutical Analyses, UKIM - Faculty of Pharmacy, Skopje, Republic of Macedonia \\ ${ }^{3}$ Research Centre for Genetic Engineering and Biotechnology "Georgi D. Efremov", Macedonian Academy of Sciences and \\ Arts, Skopje, Republic of Macedonia
}

Corresponding author: Ass. Prof. Irina Panovska - Stavridis, MD PhD, University Clinic for Hematology, Faculty of Medicine, University "Ss. Cyril and Methodus", Majka Tereza 17, 1000 Skopje, Republic of Macedonia, e-mail: dr_irina@yahoo.com

\begin{abstract}
Myelodysplastic syndrome (MDS) is a diverse group of clonal hematologic neoplasms. The only curative treatment for MDS is allogeneic stem cell transplantation (SCT). Epigenetic changes play an important role in the pathogenesis of MDS and treatment with DNA methyl transferase inhibitors, Azacitidine, significantly prolong the survival of high-risk MDS patients. Here we report a case of a 58 -year-old male presented with pancytopenia, macrocytosis, and hyperplastic bone marrow with 3-lineage dysplasia with $\sim 14 \%$ of myeloid blasts. Cytogenetic studies with $\mathrm{G}$ banding showed normal karyotype. Multiplex ligation-dependent probe amplification (MLPA) screening for most predictive cytogenetic abnormalities of MDS showed loss of the Y chromosome. Those findings later were confirmed with Quantitative Fluorescent (QF)-PCR and specific MLPA for Y chromosome, showing loss of the Y chromosome in $>80 \%$ of cells. He was diagnosed with MDS-RAEB2 according to 2008 WHO classification and stratified into high risk group (IPSS score 5). Unrelated allogeneic SCT was planed and bridging treatment with Azacitidine at a dose of $75 \mathrm{mg} / \mathrm{m} 2 /$ daily subcutaneously for 7 days every 28 days was initiated. Hematologic improvements, according to the International Working Group 2006 criteria, were observed after 4 cycles of Azacitidine treatment. After 6 cycles, complete hematological remission was achieved. Interestingly, molecular analysis performed after the 8th cycle showed normal presence of $Y$ chromosome indicating a cytogenetic remission, molecularly confirmed. Maintenance treatment with Azacitidine was assigned, and the scheduled SCT was postponed. Experience from our case showed that the loss of the Y chromosome was related to the disease onset, and indicated that Azacitidine might be consider as effective treatment for MDS cases associated with good cytogenetic
\end{abstract}

Keywords: Myelodysplastic syndrome (MDS), Azacitidine, Y chromosome.

Myelodysplastic syndrome (MDS) compromises a diverse group of clonal hematologic neoplasms characterized by a profound heterogeneity in morphologic presentation, clinical course, and cytogenetic features. [1, 2] The majority of patients with MDS show symptoms related to anemia; however, bleeding and infection are the most common causes of death. The median age of diagnosis is 72 and the median survival is 2.5 years. [1-3] About $50 \%$ of the patients display clonal chromosomal abnormalities, which are some of the most important prognostic parameters regarding MDS patients. [4-6] Patients, whose only chromosomal abnormality is a loss of the Y chromosome (LOY) have a very good prognosis according to the In- 
ternational Prognostic Scoring System (IPSS-R). The association between the LOY and MDS is debated because both phenomena are related to aging. $[6,7]$ The only potentially curative treatment for MDS is allogeneic stem cell transplantation (SCT). [1] Moreover, epigenetic changes play an important role in the pathogenesis of MDS and the treatment with DNA methyl transferase inhibitor Azacitidine and Decitabine significantly prolongs the survival of intermediate- and high-risk MDS patients. $[1,8]$

In December 2015, a 58 year old male was referred to our Institution due to pancytopenia, macrocytosis and physical complaints related to anemia. The initial peripheral blood examination revealed anemia with hemoglobin $(\mathrm{Hg})$ levels of $9.2 \mathrm{~g} / \mathrm{dl}$ ], decreased white blood cell (WBC) count of 3.4x109/1 with normal absolute neutrophil count (ANC) of $1.6 \times 109 / 1$, thrombocytopenia with platelet (Plt) count of $68 \times 109 / 1$, and $0 \%$ blasts, 3\% bands form, $47 \%$ segmented neutrophils, 3\% monocytes, $1 \%$ myelocytes and $46 \%$ lymphocytes. The bone marrow biopsy showed a hyperplastic bone marrow with 3-lineage dysplasia (Figure1) and increased number (14\%) of mononuclear myeloid blasts as determined by immunohistochemistry. During the physical examination, he was pale with a palpable spleen $1 \mathrm{~cm}$ under the rib cage (measured $14 \mathrm{~cm}$ by abdominal ultrasound examination). Flow-cytometry showed the presence of $2 \%$ CD34+ blast cells in the peripheral blood. The cytogenetic studies of the bone marrow with $\mathrm{G}$ banding has shown a normal karyotype. The multiplex ligation-dependent probe amplification (MLPA) screening for most predictive cytogenetic abnormalities in MDS [SALSA MLPA P414 MDS probe mix, MRC Holland, 1057 DL Amsterdam, the Netherlands] indicated a loss of the $\mathrm{Y}$ chromosome as the only chromosomal abnormality. This finding was later confirmed with Quantitative Fluorescent PCR and specific MLPA for the Y chromosome, showing a loss of the $\mathrm{Y}$ chromosome in $>80 \%$ of the cells. (Figure $2 \mathrm{a}$ ). The quantitative fluorescent PCR methodology included co-amplification of homologous sequences of chromosome $Y$ and other chromosomes using multiplex quantitative fluorescent (QF) PCR followed by automatic detection and analysis on ABI 3500 Genetic Analyzer. [9, 10]

These results were not consistent with the cytogenetic results and we asked the referent cytogenetic lab to reevaluate their results. They analyzed 20 metaphase cells of which 8 were with a normal karyotype and the rest had a very heterogeneous karyotype with 44 or 45 chromosomes. Since individual metaphases had a loss/gain of different chromosomes and there was no unique abnormality pertinent to at least three cells, the presence of a clonal cell population or a mosaicism could not been determined conclusively. 11 A plausible explaination for the inconsistency between the cytogenetic and molecular analyses might be a lower mitotic potential of the malignant clone.

The patient was diagnosed with MDSRAEB2 according to the 2008 WHO classification. The risk group was classified as high (score 5 ) in IPSS, high in the revised IPSS (IPSS-R), associated with a median overall survival of 21 months, and $52 \%$ probability of 2 year AML progression. [3, 5]

Allogeneic SCT was the best estimated treatment for our patient. HLA typing revealed no identical siblings. $[1,3,8,12]$ Unrelated allogeneic SCT was planned and bridging treatment with Azacitidine at a dose of $75 \mathrm{mg} / \mathrm{m} 2 /$ daily subcutaneously for 7 days every 28 days was initiated in April, 2016. The patient required a transfusion of more than 4 units of blood cells for a period of 8 weeks before being treated with Azacitidine. The risk group the patient was assigned for the Azacitidine treatment was classified as intermediate. [12]

Hematologic responses after 4 cycles of the Azacytidine treatment were considered to be hematological improvements with erythroid (HI-E) and platelet (HI-P) responses according to the International Working Group (IWG) 2006-response criteria. [13] Table 1 shows IWG responses and hematologic improvements determined just before each cycle of the Azacitidine treatment. Transient neutropenia and even lower platelet count were present until the completion of the third cycle of the treatment. Afterwards, a gradual increase in blood cells count was noted and the patient became transfusion independent.

The efficacy of the Azacitidine treatment was scored as a marrow complete remission (marrow $\mathrm{CR}$ ) with HI-E and HI-P responses (Table 1). Hematologic improvements were observed after the 4th treatment cycle and a complete hematological remission and marrow $\mathrm{CR}$ were achieved after the 6 th cycle. The percentage of myeloblasts after the 6 th cycle was $3.2 \%$. Molecular analyses performed after the 8th cycle showed normal presence of the Y chromosome indicating a molecularly confirmed, cytogenetic remission. (Figure 1b) [9] 


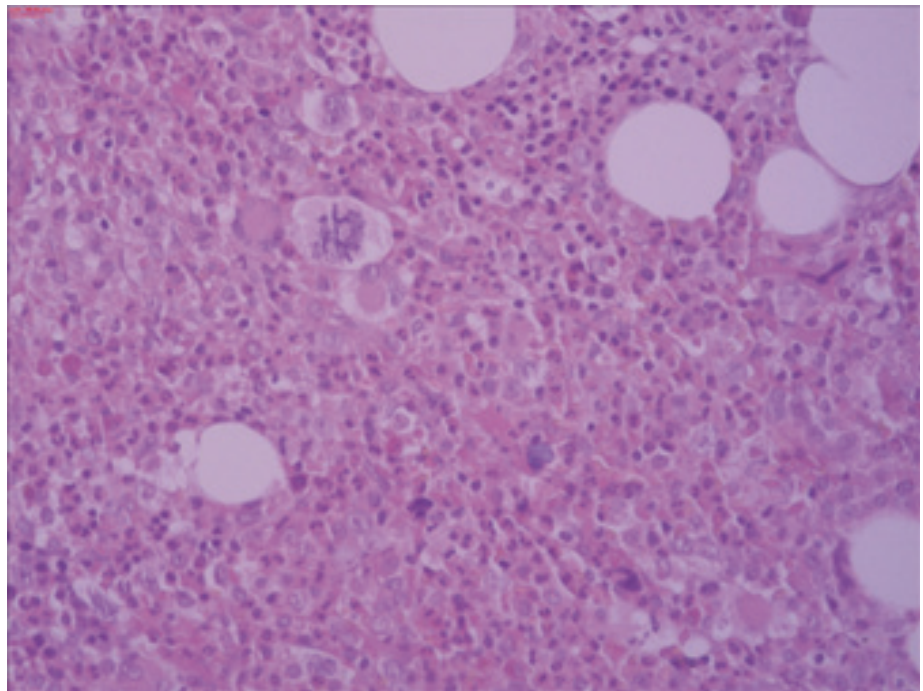

Figure 1. Bone marrow biopsy before Azacitidine treatment: hyperplastic marrow with three lineage hyperplasia and an increased number of mononuclear blast cells (Hematoxylin-Eosin stain x 200)

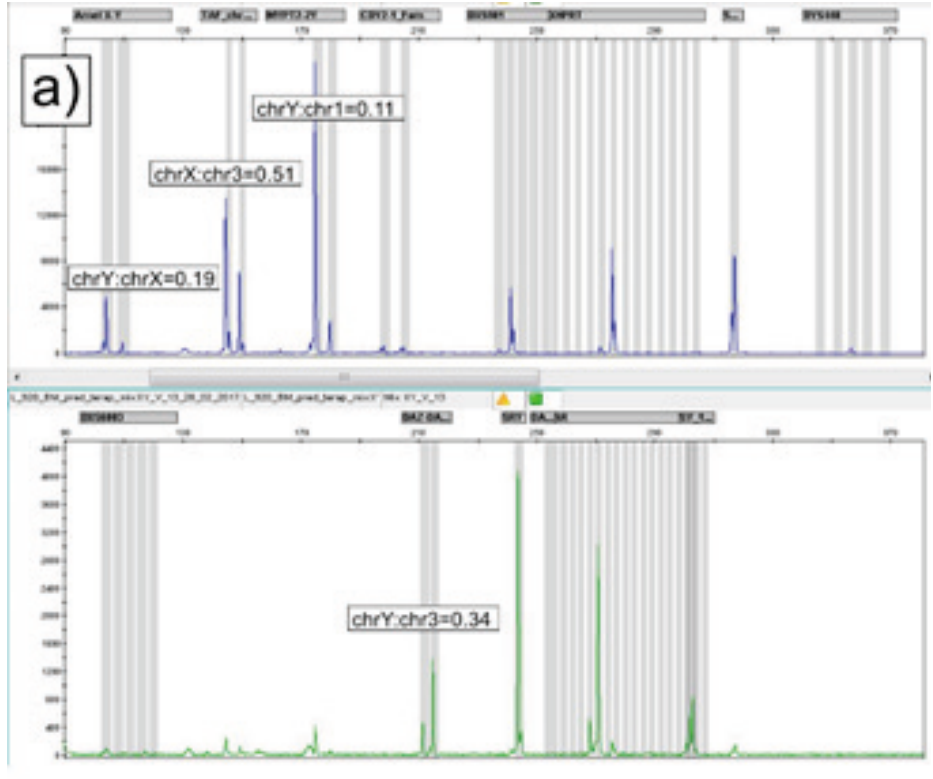

Figure 2. Quantitative Fluorescent PCR for the analysis of $Y$ chromosome loss at diagnosis [(a), $80 \%$ loss] and after 8 cycles of Azacitidine treatment [(b), normal content]
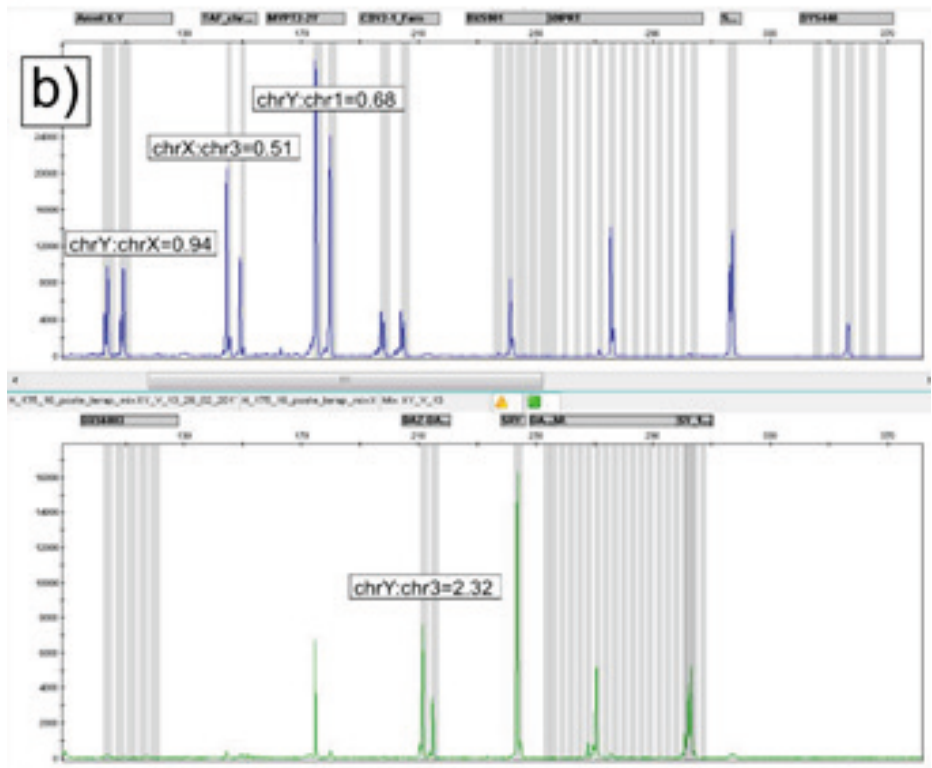
Azacitidine maintenance treatment was assigned and the scheduled SCT was postponed. A total of 9 cycles of this treatment have been completed to date. The treatment was conducted in outpatient settings and the only observed side effect of transient neutropenia was perichondritis of the right ear auricle which was quickly resolved with IV antibiotics.

The experience from our case indicated that the loss of the Y chromosome was related to the disease onset. Our results have shown that that the cytogenetic profile is the most important response predictor in MDS patients treated with Azacitidine which indicates that Azacitidine might be considered as an effective treatment for MDS cases associated with a favorable cytogenetic profile. Also, the experience with this case shows that molecular analyses of the most predictive cytogenetic abnormalities in MDS could be a powerful diagnostic tool.

Table 1. Hematologic improvements and the International Working Group (IWG) 2006-response criteria with cycles of the Azacitidine treatment

\begin{tabular}{|c|c|c|c|c|c|c|c|}
\hline \multirow[t]{2}{*}{$\begin{array}{c}\text { Cycle of } \\
\text { Azactidine }\end{array}$} & \multirow[t]{2}{*}{$\begin{array}{l}\mathrm{Hb} \\
\mathrm{g} / \mathrm{dl}\end{array}$} & \multirow[t]{2}{*}{$\begin{array}{c}\mathrm{Plt} \\
\mathrm{x} 109 / 1\end{array}$} & \multirow[t]{2}{*}{$\begin{array}{c}\mathrm{RBC} \\
\text { transfusion }\end{array}$} & \multirow[t]{2}{*}{$\begin{array}{c}\mathrm{BM} \\
\text { blasts }\end{array}$} & \multicolumn{2}{|c|}{$\begin{array}{l}\text { Hematological } \\
\text { improvements }\end{array}$} & \multirow[t]{2}{*}{$\begin{array}{c}\text { IWG } 2006 \\
\text { response criteria }\end{array}$} \\
\hline & & & & & $\begin{array}{c}\mathrm{HI}-\mathrm{E} \\
(>1.5 \mathrm{~g} / \mathrm{dl}) \\
\end{array}$ & $\begin{array}{c}\text { HI-P } \\
(>30 \times 109 / 1) \\
\end{array}$ & \\
\hline 0 & 8.2 & 38 & + & $14 \%$ & - & - & $\mathrm{SD}$ \\
\hline 1 & 8.0 & 35 & + & ND & - & - & SD \\
\hline 2 & 9.1 & 26 & - & ND & - & - & $\mathrm{SD}$ \\
\hline 3 & 9.7 & 44 & - & ND & + & + & HI-P \\
\hline 4 & 10.1 & 93 & - & ND & + & + & HI-E and HI-P \\
\hline 5 & 14.2 & 185 & - & ND & + & + & HI-E and HI-P \\
\hline 6 & 16.0 & 250 & - & $3.2 \%$ & + & + & $\begin{array}{c}\text { marrow CR with } \\
\text { HI-E and HI-P }\end{array}$ \\
\hline 7 & 16.6 & 220 & - & ND & + & + & HI-E and HI-P \\
\hline 8 & 15.9 & 152 & - & ND & + & + & $\begin{array}{c}\text { marrow CR with } \\
\text { HI-E and HI-P }\end{array}$ \\
\hline 9 & 15.8 & 188 & - & ND & + & + & $\mathrm{SD}$ \\
\hline
\end{tabular}

\section{REFERENCES}

1. Tefferi A, Vardiman JW. Myelodysplastic syndromes. N Engl J Med 2009;361(19):1872-1885.

2. Vardiman JW, Harris NL, Brunning RD.The World Health Organization (WHO) classification of the myeloid neoplasms. Blood 2002;100(7):2292-302.

3. Malcovati L, Germing U, Kuendgen A, Della Porta $\mathrm{MG}$, Pascutto $\mathrm{C}$, Invernizzi R, Giagounidis A, Hildebrandt B, Bernasconi P, Knipp S, Strupp C, Lazzarino M, Aul C, Cazzola M. Time-dependent prognostic scoring system for predicting survival and leukemic evolution in myelodysplastic syndromes. J Clin Oncol 2007; 25(23): 3503-10.
4. Greenberg P1, Cox C, LeBeau MM, Fenaux P, Morel P, Sanz G, Sanz M, Vallespi T, Hamblin T, Oscier D, Ohyashiki K, Toyama K, Aul C, Mufti G, Bennett J. International scoring system for evaluating prognosis in myelodysplastic syndromes. Blood. 1997;89(6): 2079-2088

5. Greenberg PL1, Tuechler H, Schanz J, Sanz G, Garcia-Manero G, Solé F, Bennett JM, Bowen D, Fenaux P, Dreyfus F, Kantarjian H, Kuendgen A, Levis A, Malcovati L, Cazzola M, Cermak J, Fonatsch C, Le Beau MM, Slovak ML, Krieger O, Luebbert M, Maciejewski J, Magalhaes SM, Miyazaki Y, Pfeilstöcker M, Sekeres M, 
Sperr WR, Stauder R, Tauro S, Valent P, Vallespi T, van de Loosdrecht AA, Germing U, Haase D.Revised international prognostic scoring system for myelodysplastic syndromes. Blood 2012;120(12):2454-65

6. A Pardanani, A Tefferi. Cytogenetic risk stratification in myelodisplastic syndromes: Are we there yetJ J Clin ONcol 2012;30:2703-2704

7. Wong AK,Fang B, Zhang L, Guo X, Lee S, Schreck R. Loss of the Y Chromosome An Age-Related or Clonal Phenomenon in Acute Myelogenous Leukemia/ Myelodysplastic Syndrome? Arch Pathol Lab Med 2008;132:1329-32

8. Fenaux P, Mufti GJ,et al. Efficacy of azacitidine compared with that of conventional care regimens in the treatment of higher-risk myelodysplastic syndromes: a randomised, open-label, phase III study.Lancet Oncol 2009;10:223-32.

9. Plaseski T, Noveski P, Trivodalieva S, Efremov GD, Plaseska-Karanfilska D.. Quantitative fluorescent-PCR detection of sex chromosome aneuploidies and AZF deletions/duplications. Genet Test. 2008;12(4):595-605.

10. Noveski P, Madjunkova S, Sukarova-Stefanovska E, Matevska Geshkovska N, Kuzmanovska M, Dimovski A, Plaseska-Karanfilska D. Loss of $\mathrm{Y}$ chromosome in peripheral blood of colorectal and prostate cancer patients. PLoS One. 2016;11(1):e0146264

11. Steensma DP, Bejar R, Jaiswal S, Lindsley RC, Sekeres MA, Hasserjian RP, Ebert BL. Clonal hematopoiesis of indeterminate potential and its distinction from myelodysplastic syndromes. Blood. 2015; 126(1): 9-16.

12. Itzykson R1, Thépot S, Quesnel B, Dreyfus F, Beyne-Rauzy O, Turlure P, Vey N, Recher C, Dartigeas C, Legros L, Delaunay J, Salanoubat C, Visanica S, Stamatoullas A, Isnard F, Marfaing-Koka A, de Botton S, Chelghoum Y, Taksin AL, Plantier I, Ame S, Boehrer S, Gardin C, Beach CL, Adès L, Fenaux P; Groupe Francophone des Myelodysplasies(GFM). Prognostic factors for response and overall survival in 282 patients with higher-risk myelodysplastic syndromes treated with azacitidine. Blood 2011;117:403-411

13. Bruce D. Cheson, Peter L. Greenberg, John M. Bennett, et al. Clinical application and proposal for modification of the International Working Group (IWG) response criteria in myelodysplasia. Blood 2006; 108(2):419-25 


\title{
Резиме
}

\section{МОЛЕКУЛАРНО ПОТВРДЕНА ЦИТОГЕНЕТСКА РЕМИСИЈА ПО ТРЕТМАН СО АZАСУТIDINE КАЈ ПАЦИЕНТ СО МИЕЛОДИСПЛАСТИЧЕН СИНДРОМ}

\author{
Ирина Пановска-Ставридис ${ }^{1}$, Мартин Ивановски ${ }^{1}$, Сања Трајкова ${ }^{1}$, \\ Александра Пивкова-Вељановска ${ }^{1}$, Марија Попова-Лабаческа ${ }^{1}$, Надица Матевска-Гешковска ${ }^{2}$, \\ Предраг Новески ${ }^{3}$, Дијана Плашеска-Каранфилска ${ }^{3}$, Лидија Чевреска ${ }^{1}$, Александар Ј. Димовски ${ }^{2}$ \\ ${ }^{1}$ Универзитетска клиника за Хематологија, Универзитет „Св. Кирил и Методиј“, Медицински факултет \\ - Скопје, Република Македонија \\ ${ }^{2}$ Центар за биомолекуларни фармацевтски студии, Универзитет „Св. Кирил и Методиј“, Медицински \\ факултет - Скопје, Република Македонија \\ ${ }^{3}$ Истражувачки центар за генетско инженерство и биотехнологија „Георги Д. Ефремов“, \\ Македонска академија на науките и уметностите, Скопје, Република Македонија
}

Миелодиспластичните синдроми (МДС) се група разновидни клонални хематолошки неоплазми. Единствена куративна опција за МДС претставува алогената трансплантација на матични хематопоетски клетки (ТМХК). Значајна улога во патогенезата на МДС имаат епигенетските промени и третманот со метил трансферазниот инхибитор Azacitidine, кој значително го продолжува преживувањето, особено на високо ризичните случаи на МДС.

Во студијата е прикажан 58-годишен пациент, кој беше упатен на нашата клиника поради панцитопенија, макроцитоза и наод за хиперпластична коскена срцевина асоцирана со трилиниска дисплазија и $~ 14 \%$ миелоидни бластни клетки. Пациентот имаше уреден кариотип, но испитувањата со MLPA за најчестите цитогентски абнормалности открија губење на Y-хромозомот. Овој наод беше потврден со QF-PCR и специфична MLPA за Y-хромозомот; во 80\% од клетките недостигаше Y-хромозомот. Според класификацијата на WHO од 2008 година, пациентот беше дијагностициран како MDS-RAEB2 и стратифициран како високо ризичен пациент (IPSS скор 5). Терапијата на избор за овој пациент беше несродна ТМХК и беше започнат период на премостување co Azacitidine, во доза од $75 \mathrm{mg} / \mathrm{m} 2$ дневно во текот на седум последователни дена. Подобрувања во хематолошките параметри, според International Working Group 2006, беа евидентирани по четири циклуси терапија, а по шест беше постигната комплетна хематолошка ремисија. Молекуларните анализи спроведени по осмиот циклус покажаа нормално присуство на Ү-хромозом, односно на молекуларно ниво беше потврдена комплетна цитогенетска ремисија. Планираната ТМХК беше одложена и тој беше ставен на терапија на одржување со Azacitidine, која е сѐ уште во тек.

Искуството од овој случај покажа дека губењето на Ү-хромозомот настанало како резултат на појава на болеста и тоа укажа дека Azcitidine треба да се има предвид како ефикасна тераписка опција кај МДС случаите асоцирани со поволен цитогенетски профил.

Клучни зборови: миелодипластичен синдром, azacytidine, Y-хромозом 